\title{
SEED DISPERSAL, SEEDBANK, SEEDLING SURVIVAL, AND INITIAL GROWTH OF THREE CAATINGA TREES ${ }^{1}$
}

\author{
IVONETE ALVES BAKKE², JOSÉ EVANALDO RANGEL DA SILVA², OLAF ANDREAS BAKKE ${ }^{2 *}$, \\ ANTONIO LUCINEUDO DE OLIVEIRA FREIRE ${ }^{2}$
}

\begin{abstract}
Myracrodruon urundeuva, Handroanthus impetiginosus and Amburana cearensis are Caatinga tree species that produce valuable timber, but little is known about their ecology. The objective of this study was to evaluate the seed distribution of these species on the forest floor before and after seed dispersal; and seedling emergence, survival, and growth during the rainy season after dispersal of seeds. There were no remaining viable seeds of these species in the seedbank before seed dispersal. The average numbers of seeds after seed dispersal were 188 seed $\mathrm{m}^{-2}$ in a $30 \mathrm{~m}$ radius around $M$. urundeuva, $9 \mathrm{seed} \mathrm{m}^{-2}$ in a $10 \mathrm{~m}$ radius around $H$. impetiginosus, and $5 \mathrm{seed}^{-2}$ in a $20 \mathrm{~m}$ radius around $A$. cearensis. The distance of seed dispersal reached 30, 20, and $10 \mathrm{~m}$ for $M$. urundeuva, $H$. impetiginosus, and $A$. cearensis trees, respectively, due to differences in tree height, seed weight, forest density, and wind intensity. Seedling emergence was observed during 4 (M. urundeuva) and 9 ( $H$. impetiginosus and A. cearensis) weeks. High mortality predominated at the beginning and end of the rainy season for M. urundeuva and A. cearensis, respectively, while practically all $H$. impetiginosus seedlings survived. M. urundeuva showed the highest mortality but had higher number of established seedlings than the other species. Seedling survival peaked around $5 \mathrm{~m}$ from the tree base. Seedling recruitment and natural regeneration of these trees are assured in the Caatinga site evaluated.
\end{abstract}

Keywords: Natural regeneration. Aroeira. Ipê roxo. Cumarú. Seedling emergence.

\section{DISPERSÃO, BANCO DE SEMENTES, SOBREVIVÊNCIA E CRESCIMENTO INICIAL DE TRÊS ÁRVORES DA CAATINGA}

RESUMO - Myracrodruon urundeuva, Handroanthus impetiginosus e Amburana cearensis são árvores da caatinga que produzem madeira valiosa, mas pouco se conhece sobre sua ecologia. Avaliou-se a distribuição de suas sementes no solo antes e após a dispersão, a emergência, a sobrevivência e o crescimento das mudas na estação chuvosa após a dispersão. Não havia sementes viáveis remanescentes dessas espécies no banco de sementes antes da dispersão. Após a dispersão, foram observadas, em média, 188 sementes $\mathrm{m}^{2}$ em um raio de $30 \mathrm{~m}$ em torno das M. urundeuva, 9 sementes $\mathrm{m}^{-2}$ em um raio de $10 \mathrm{~m}$ das $H$. impetiginosus e 5 sementes $\mathrm{m}^{-2}$ em um raio de $20 \mathrm{~m}$ ao redor das $A$. cearensis. A distância de dispersão atingiu 30,20 e $10 \mathrm{~m}$ para $M$. urundeuva, $H$. impetiginosus e $A$. cearensis, respectivamente, certamente devido a diferenças na altura das árvores, no peso das sementes, na densidade da floresta e intensidade do vento. A emergência das plântulas foi observada durante 4 (M. urundeuva) e 9 (H. impetiginosus e A. cearensis) semanas. A mortalidade predominou no início e no final da estação chuvosa para $M$. urundeuva e A. cearensis, respectivamente, enquanto praticamente todas as mudas de $H$. impetiginosus sobreviveram. Myracrodruon urundeuva apresentou a maior taxa de mortalidade, mas estabeleceu mais mudas do que as outras espécies. A sobrevivência das mudas mostrou-se máxima a aproximadamente 5 metros das árvores. O recrutamento de mudas e a regeneração natural dessas árvores estão assegurados nesta área de Caatinga.

Palavras-chave: Regeneração natural. Aroeira. Ipê roxo. Cumarú. Emergência de mudas.

\footnotetext{
${ }^{*}$ Corresponding author

${ }^{1}$ Received for publication in 04/04/2020; accepted in 07/18/2020.

Paper extracted from the graduation monograph of the second author

${ }^{2}$ Forestry Academic Unit/Center of Rural Health and Technology, Universidade Federal de Campina Grande, Patos, PB, Brazil; ivobakke@gmail.com - ORCID: 0000-0002-6015-6977, naldoflorestal@yahoo.com.br - ORCID: 0000-0002-1994-0145, obakke@cstr.ufcg.edu.br - ORCID: 0000-0003-2324-0165, lucineudofreire@gmail.com - ORCID: 0000-0002-6477-8554.
} 


\section{INTRODUCTION}

The Caatinga Biome covers most of the Brazilian northeast region; it is characterized by semiarid climate and high levels of biodiversity and endemism. However, human pressure on Caatinga vegetation, especially trees, for firewood extraction and shifting cultivation has negatively impacted the biodiversity and soil in this biome, triggering desertification processes in large areas, impacting its flora, seedbank, diversity, and species abundance (FERNANDES; QUEIROZ, 2018). According to Fernandes and Queiroz (2018), the natural regeneration process is determined mainly by the seedbank and seed rain, which are affected by the vegetation composition and disperser agents, such as wind and animals; however, many Caatinga sites are clear cut without considering the autecology and contribution of each species to the ecosystem, and other ecological factors that interfere with forest regeneration, such as patterns and ranges of seed dispersal. In addition, they consider that the failure to minimally understand the effects of these factors on the vegetation composition may result in large land areas without a proper source of propagules, quantitatively and qualitatively hindering the natural processes of vegetation regeneration.

The lack of ecological information is a problem for Myracrodruon urundeuva (Allem.) (Anacardiaceae), Handroanthus impetiginosus (Mart ex DC.) Standl (Bignoniaceae), and Amburana cearensis (Allem) A.C. Smith, (Fabaceae) species, locally known as aroeira, ipê-roxo, and cumarú, respectively. These are xerophilous, long-lived tree species that, according to the Red Book of Brazilian Flora, deserve attention due to their declining populations resulting from heavy wood exploitation (MARTINELLI; MORAES, 2013). Their phenology is similar in many aspects: the onset of the dry season triggers flowering and anemochorous dispersal of their winged seeds; and, at the beginning of the following moist season, the seeds germinate (GOMES; QUIRINO, 2016; LIMA et al., 2008).

However, the seeds produced by $M$. urundeuva, $H$. impetiginosus, and $A$. cearencis present marked differences in weight, with ratios of $1: 37$ or higher, and in size, with ratios of $1: 4$ to $1: 7$ (LIMA et al., 2008; SIQUEIRA FILHO et al., 2009). According to Silva and Rodal (2009), differences on seed weight and size, density of forest canopy, phytosociological position of the tree in the forest, and winds affect the distance and direction of dispersal of anemochorous propagules.

Therefore, we hypothesized that the pattern of seed dispersal is not homogeneous around the parent trees, and that each species shows differences in distance of seed dispersal, and in seedling emergence, survival, and growth during the rainy season after the dispersal of seeds (GOMES; QUIRINO, 2016; SILVA; RODAL, 2009). Thus, we evaluated the seedbank of Myracrodruon urundeuva, Handroanthus impetiginosus, and Amburana cearensis just before and after the dispersal of seeds, the pattern of seed dispersal and seedling emergence and survival around the trees, and seedling growth in the rainy season following seed dispersal in a Caatinga forest remnant.

\section{MATERIAL AND METHODS}

This study was carried out from August 2007 to July 2009 at the Fazenda Tamanduá's Particular Reserve of the Natural Patrimony (Portuguese abbreviation: RPPN) $\left(07^{\circ} 00^{\prime} \mathrm{S} ; 37^{\circ} 24^{\prime} \mathrm{W}\right)$, in Santa Terezinha, Paraíba State, Brazil. This RPPN was created in 1998 (BRASIL, 1998) and comprises 325 ha of protected forest since 1980 .

In August 2007, a three-people team collected data on tree height $(\mathrm{H})$, crown diameter, and diameter at breast height $(\mathrm{DBH})$ from three adult healthy flowering trees of each species (a total of nine sampled trees), visually chosen to be at least $100 \mathrm{~m}$ apart of another flowering individual of the same species. Tree height was estimated by using a Blume-Leiss clinometer; crown diameter by averaging two perpendicular measures of crown diameter considering their projection on the soil; and DBH was obtained by converting the value of the circumference at breast height measured directly on tree trunk. Crown diameter and DBH values were based on measures carried out using a tape measure.

The respective values for these characteristics averaged $9.3 \mathrm{~m}, 7.6 \mathrm{~m}$, and $21.7 \mathrm{~cm}$ for $M$. urundeuva; $6.7 \mathrm{~m}, 7.2 \mathrm{~m}$, and $16.2 \mathrm{~cm}$ for $H$. impetiginosus; and $8.5 \mathrm{~m}, 11.0 \mathrm{~m}$, and $42.6 \mathrm{~cm}$ for $A$. cearensis. These trees had dominant or co-dominant position in a dense forest, where the tree canopies covered $100 \%$ of the soil surface, except for one $H$. urundeuva and two A. cearensis trees located in relatively more open forest sites.

We devised a protocol in which points at 1, 5, 10,20 , and $30 \mathrm{~m}$ of horizontal distance from the trunk were marked with wooden pickets that were stuck into the soil in the north, south, east, and west positions from each sampled tree, with the help of a compass and a tape measure, totaling 20 and 60 marked points for each tree and species, respectively. Circular plots $\left(0.5-\mathrm{m}^{2}\right.$ plots, equivalent to a circle with an approximate diameter of $0.80 \mathrm{~m}$, for $M$. urundeuva, as it produces many small seeds; and $1.2-\mathrm{m}^{2}$ plots, equivalent to a circle with an approximate diameter of $1.24 \mathrm{~m}$, for $H$. impetiginosus and $A$. cearensis, because they 
produce small quantities of large seeds) were centered in each of these points and used for biweekly data collection of seedling emergence and survival under field conditions, from March to July 2008 (M. urundeuva and A. cearensis) and from February to July 2009 (H. impetiginosus).

The seedbank was also studied under greenhouse conditions. According to the procedures used by Costa and Araújo (2003), forest floor material (litter and $5-\mathrm{cm}$ top soil) was collected in similar 0.5 and $1.2 \mathrm{~m}^{2}$ circular plots positioned perpendicularly and at 1-m apart from each marked point around the trees, before seed dispersal in August 2007 (M. urundeuva and A. cearensis) and in August 2008 (H. impetiginosus). Similar procedures were followed to collect forest floor material, after seed dispersal, in circular plots at 1-m apart from each marked point around the trees and on the opposite side of the previously plots sampled before the dispersal of seeds. This post-dispersal sampling was carried out in October and September 2007 (M. urundeuva and A. cearensis, respectively) and in September 2008 (H. impetiginosus).

After collection, the forest floor material from each circular plot was placed in plastic bags and sent to the seedling nursery facilities at the Federal University of Campina Grande, Patos campus, Brazil, where they were placed in $22 \times 15 \times 5 \mathrm{~cm}$ plastic trays, arranged on workbenches covered with a $25 \%$ shade screen, and watered twice a day for 12 weeks, when the seedling emergence data were collected weekly (COSTA; ARAÚJO, 2003, adapted). The seeds that germinated in washed sand were used for comparisons to identify the seedlings emerged from the collected forest floor material.

This devised protocol enabled the determination of the number of seedlings for each species emerged from the forest floor material collected in $600.5-\mathrm{m}^{2}$ plots $(\varnothing=0.80 \mathrm{~m})$, for $M$. urundeuva under greenhouse conditions; and in 60 $1.2-\mathrm{m}^{2}$ plots $(\varnothing=1.24 \mathrm{~m})$, for $H$. impetiginosus and $A$. cearensis under greenhouse conditions; and from the forest floor material in 60 similar circular plots in the field. The number of emerged seedlings was determined according to the horizontal distance $(1,5$, 10,20 , or $30 \mathrm{~m}$ ) from the tree base to the north, south, east, and west transects. This procedure enabled the estimation of the average number of emerged seedlings per $\mathrm{m}^{2}$ (BASKIN; BASKIN, 1998) or hectare, considering the area of the sampled plots, adult trees equally spaced in the forest environment, and the areas of the three 0.80 - and 1.24-m-wide belts centered at $1,5,10,20$, or $30 \mathrm{~m}$ around the tree in which emerged seedlings were found.

\section{RESULTS AND DISCUSSION}

Under greenhouse conditions, no seedlings emerged from the forest floor material collected at different distances around the studied tree species before seed dispersal, but seedlings emerged from the forest floor material sampled after seed dispersal. The lack of emerged seedlings from the forest floor material collected before seed dispersal indicates that no viable seeds of these trees remain in the forest floor from one dispersal event to another. Although the elapsed time between two events of dispersal of seeds of the same plant is not clearly reported in literature for these studied tree species, Lúcio, Silva and Lopes (2010) reported that all viable $A$. cearensis seeds germinated during the first rainy season after seed dispersal.

The sampled material collected in the 60 circular plots around M. urundeuva trees, after seed dispersal, presented the following results: 1,884 emerged seedlings, from which $36.24 \%, 31.64 \%$, $22.25 \%$, and $9.87 \%$ emerged from the material collected in the west, north, east, and south transects, respectively (Table 1 ); $141 \quad H$. impetiginosus seedlings, from which $31.21 \%, 26.24 \%, 24.82 \%$, and $17.73 \%$ emerged from the material collected in the north, south, west, and east transects, respectively; and $97 \mathrm{~A}$. cearensis seedlings, from which $42.27 \%$, $29.90 \%, 18.55 \%$, and $9.28 \%$ emerged from material collected in the north, south, west, and east transects, respectively.

The differences in the number of emerged seedlings between transects were probably due to the direction of prevailing winds and the anemochorous characteristics of the seeds; and the differences in distance of seed dispersal (10-to-30m from the tree) and in number of seedling per area were due to the weight and quantity of seeds produced, respectively. Hypothetically, distance of seed dispersal is more important for propagation of a species than the direction to which the seeds are dispersed, as no significant difference is supposed to exist in a continuous forest environment resulting from a prior or post position from a tree, or from a position more to the right or more to the left from a tree.

Only M. urundeuva trees dispersed their seeds up to $30 \mathrm{~m}$ from the tree (in the north direction). Considering that seed dispersal may reach all the sampled $600.5-\mathrm{m}^{2}$ circular plots $(3 \times 20)$, i.e., a sampling area of $30 \mathrm{~m}^{2}$, up to $30 \mathrm{~m}$ away from the three $M$. urundeuva trees considered in the present study, the 1,884 seedlings that emerged from the forest floor material collected averaged 62.8 seedling $\mathrm{m}^{-2}$ in the first $30 \mathrm{~m}$ around the trees, which is equivalent to 628,000 seedlings $\mathrm{ha}^{-1}$ if trees were regularly spaced (every $60 \mathrm{~m}$ ) in the forest. 
Table 1. Number (X) and percentage (\%) of seedlings emerged under greenhouse conditions, from material collected in forest floors under trees of the species Myracrodruon urundeuva $\left(600.5-\mathrm{m}^{2}\right.$ circular plots), Handroanthus impetiginosus, and Amburana cearensis (60 1.2- $\mathrm{m}^{2}$ circular plots for both species), according to the distance $(1,5,10,20$, and $30 \mathrm{~m})$ and transects (North, South, East, and West) from the parent tree.

\begin{tabular}{|c|c|c|c|c|c|c|c|c|c|c|}
\hline \multirow{3}{*}{$\begin{array}{l}\text { Distance from } \\
\text { the parent tree }(\mathrm{m})\end{array}$} & \multicolumn{8}{|c|}{ Transect } & & \\
\hline & \multicolumn{2}{|c|}{ North } & \multicolumn{2}{|c|}{ South } & \multicolumn{2}{|c|}{ East } & \multicolumn{2}{|c|}{ West } & \multicolumn{2}{|c|}{ Total } \\
\hline & $\mathrm{X}$ & $\%$ & $\bar{X}$ & $\%$ & $\mathrm{X}$ & $\%$ & $\mathrm{X}$ & $\%$ & $\bar{X}$ & $\%$ \\
\hline \multicolumn{11}{|c|}{ M. urundeuva } \\
\hline 1 & 362 & 19.21 & 186 & 9.87 & 276 & 14.65 & 332 & 17.62 & 1156 & 61.36 \\
\hline 5 & 204 & 10.83 & 00 & 0.00 & 136 & 7.22 & 310 & 16.45 & 650 & 34.50 \\
\hline 10 & 26 & 1.38 & 00 & 0.00 & 05 & 0.27 & 37 & 1.96 & 68 & 3.61 \\
\hline 20 & 02 & 0.11 & 00 & 0.00 & 02 & 0.11 & 03 & 0.16 & 07 & 0.37 \\
\hline 30 & 02 & 0.11 & 00 & 0.00 & 00 & 0.00 & 01 & 0.05 & 03 & 0.16 \\
\hline Total & 596 & 31.64 & 186 & 9.87 & 419 & 22.25 & 683 & 36.24 & 1884 & 100.00 \\
\hline \multicolumn{11}{|c|}{ H. impetiginosus } \\
\hline 1 & 30 & 21.28 & 36 & 25.53 & 18 & 12.77 & 24 & 17.02 & 108 & 76.60 \\
\hline 5 & 12 & 8.51 & 01 & 0.71 & 07 & 4.96 & 10 & 7.09 & 30 & 21.27 \\
\hline 10 & 02 & 1.42 & 00 & 0.00 & 00 & 0.00 & 01 & 0.71 & 03 & 2.13 \\
\hline 20 & 00 & 0.00 & 00 & 0.00 & 00 & 0.00 & 00 & 0.00 & 00 & 0.00 \\
\hline 30 & 00 & 0.00 & 00 & 0.00 & 00 & 0.00 & 00 & 0.00 & 00 & 0.00 \\
\hline Total & 44 & 31.21 & 37 & 26.24 & 25 & 17.73 & 35 & 24.82 & 141 & 100.00 \\
\hline \multicolumn{11}{|c|}{ A. cearensis } \\
\hline 1 & 20 & 20.63 & 15 & 15.46 & 09 & 9.28 & 20 & 20.62 & 64 & 65.99 \\
\hline 5 & 14 & 14.43 & 03 & 3.09 & 00 & 0.00 & 09 & 9.28 & 26 & 26.80 \\
\hline 10 & 04 & 4.12 & 00 & 0.00 & 00 & 0.00 & 00 & 0.00 & 04 & 4.12 \\
\hline 20 & 03 & 3.09 & 00 & 0.00 & 00 & 0.00 & 00 & 0.00 & 03 & 3.09 \\
\hline 30 & 00 & 0.00 & 00 & 0.00 & 00 & 0.00 & 00 & 0.00 & 00 & 0.00 \\
\hline Total & 41 & 42.27 & 18 & 18.55 & 09 & 9.28 & 29 & 29.90 & 97 & 100.00 \\
\hline
\end{tabular}

Handroanthus impetiginosus trees dispersed their seed up to $10 \mathrm{~m}$ (to north and west directions); 12 sampled $1.2-\mathrm{m}^{2}$ circular plots up to $10 \mathrm{~m}$ apart from each other, totaling 36 plots up to $10 \mathrm{~m}$ apart from the three trees were considered in the present study. Considering that seed dispersal may reach these $361.2-\mathrm{m}^{2}$ plots $\left(43.2 \mathrm{~m}^{2}\right)$, the 141 seedlings emerged from the forest floor material collected in those plots up to $10 \mathrm{~m}$ distant from the three Handroanthus impetiginosus trees averaged 3.3 seedling $\mathrm{m}^{-2}$ in the first $10 \mathrm{~m}$ around the trees, corresponding to 32,638 seedling $\mathrm{ha}^{-1}$ if adult trees were $20 \mathrm{~m}$ apart from each other. Amburana cearensis trees dispersed their sees up to $20 \mathrm{~m}$ (to the north direction). Considering the floor material collected in $481.2 \mathrm{~m}^{2}$ circular plots $(3 \times 16)$ up to 20 $\mathrm{m}$ from the three $A$. cearensis trees, the $97 A$. cearensis seedlings emerged from these material averaged 1.7 seedling $\mathrm{m}^{-2}$, corresponding to 16,840 seedling $\mathrm{ha}^{-1}$ if adult trees were regularly $40 \mathrm{~m}$ apart from each other.

These trees produce winged seeds that are dispersed by anemochory. Thus, forest canopy density, phytosociological position of the tree in the forest, wind speed, and seed weight, size, and shape may affect the distance of seed dispersal (SILVA; RODAL, 2009). Then, in addition to the height of $M$. urundeuva trees (average of $9.3 \mathrm{~m}$ ), their numerous light $(\sim 0.01 \mathrm{~g}$ per seed) and small $(0.40 \mathrm{~cm}$ wide and $0.35 \mathrm{~cm}$ long fruits) seeds (LIMA et al., 2008; SIQUEIRA FILHO et al., 2009) allowed a relatively large amount of seeds to disperse up to $30 \mathrm{~m}$ from the tree, even if the trees were in a forest with a relatively dense canopy.

In addition to the height of Amburana cearensis trees (average of $8.5 \mathrm{~m})$, the weight $(0.37$ to $\left.0.56 \mathrm{~g} \mathrm{seed}^{-1}\right)$ and size $(1.67 \mathrm{~cm}$ wide and $1.15 \mathrm{~cm}$ long) of their seeds (LIMA et al., 2008; SIQUEIRA FILHO et al., 2009) contributed to the decrease in seed dispersal distance to $20 \mathrm{~m}$, even though these trees were in relatively more open forests. The maximum 10-m dispersal distance found for $H$. impetiginosus seeds was not consistent with their intermediate weight $\left(0.11\right.$ to $\left.0.17 \mathrm{~g} \mathrm{seed}^{-1}\right)$ and relatively large size $(3.0 \mathrm{~cm}$ wide wings and $1.4 \mathrm{~cm}$ long seeds) (LIMA et al., 2008; SIQUEIRA FILHO et al., 2009). This short distance of seed dispersal may be due to the average tree height $(6.7 \mathrm{~m})$ and because the trees were in a forest with a relatively dense canopy.

The seed dispersal found for these trees during the dry season may contribute to the increase in seed dispersal distance, because the general leaf senescence of Caatinga trees reduces the forest canopy density (SILVA; RODAL, 2009). However, only $M$. urundeuva showed potential to disperse seeds and eventually establish new plants up to $30 \mathrm{~m}$ distant from the tree, beyond its average crown diameter of $7.6 \mathrm{~m}$. Thus, $60 \mathrm{~m}$ should be the maximum distance between two adult $M$. urundeuva trees in a Caatinga forest to assure the presence of their seeds in the seedbank stock by anemochory. 
Equivalently, more $H$. impetiginosus and $A$. cearensis trees should be present in a forest area than $M$. urundeuva, as their seeds disperse to shorter distances from the tree.

Most viable $M$. urundeuva, H. impetiginosus, and $A$. cearensis seeds (respectively 98.83\%, $95.04 \%$, and $78.35 \%$ ) from the sampled forest floor material emerged in the first four weeks under greenhouse conditions, while few new seedlings emerged in the following two weeks and none emerged in the following six weeks of evaluation. Fast seedling emergence is frequently found for many Caatinga species (MEIADO, 2014; COSTA; ARAÚJO, 2003), including tree species such as Poincianela pyramidalis (Tul.) L. P. Queiroz and Anadenanthera colubrina (Vell.) (SANTOS et al., 2016).

A fast seedling emergence of Caatinga species was observed in many studies, such as Costa and Araújo (2003). The offspring of these species completes the vegetative cycle within the short rainy season (annual species) or needs a maximum period with favorable soil moisture to grow and establish during the first growing season (perennial species). This certainly increases the chances for regenerating perennial plants species to survive the six-to-seven month long dry season and resume growth in the following rainy season.

Considering the $452 \mathrm{M}$. urundeuva seedlings that emerged in the field plots, $48 \%$ (218 seedlings) survived to the end of the first rainy season after seed dispersal (July 2008) (Table 2). Almost all emerged $H$. impetiginosus seedlings survived (105 out of 106 , or $99 \%$ ) to the end of the first rainy season (July 2009); considering the 55 A. cearensis seedlings that emerged in the field plots, $78 \%$ (43 seedlings) survived to the end of the first rainy season (July 2008). All seedlings that emerged in field were in plots distant $10 \mathrm{~m}$ or less from the trees.

Table 2. Number of emerged (X) and surviving (Y) seedlings in the field at the end of the first rainy season (July 2008, for Myracrodruon urundeuva and Amburana cearensis; and July 2009, for Handroanthus impetiginosus) after seed dispersal on 60 circular plots of $0.5 \mathrm{~m}^{2}$ (M. urundeuva) or $1.2 \mathrm{~m}^{2}$ (H. impetiginosus and A. cearensis), according to the distance from the tree along north, south, east, and west transects.

\begin{tabular}{|c|c|c|c|c|c|c|c|c|c|c|}
\hline \multirow{3}{*}{$\begin{array}{c}\text { Distance } \\
\text { from the tree }\end{array}$} & \multicolumn{8}{|c|}{ Transects } & & \\
\hline & \multicolumn{2}{|c|}{ North } & \multicolumn{2}{|c|}{ South } & \multicolumn{2}{|c|}{ East } & \multicolumn{2}{|c|}{ West } & \multicolumn{2}{|c|}{ Total } \\
\hline & $\mathrm{X}$ & $\mathrm{Y}$ & $\mathrm{X}$ & $\mathrm{Y}$ & $\mathrm{X}$ & $\mathrm{Y}$ & $\mathrm{X}$ & $\mathrm{Y}$ & $\bar{X}$ & $\mathrm{Y}$ \\
\hline & \multicolumn{10}{|c|}{ M. urundeuva } \\
\hline 1 & 93 & 04 & 52 & 36 & 80 & 35 & 56 & 25 & 281 & 100 \\
\hline 5 & 161 & 108 & 00 & 00 & 00 & 00 & 06 & 06 & 167 & 114 \\
\hline 10 & 02 & 02 & 00 & 00 & 00 & 00 & 02 & 02 & 04 & 04 \\
\hline 20 & 00 & 00 & 00 & 00 & 00 & 00 & 00 & 00 & 00 & 00 \\
\hline 30 & 00 & 00 & 00 & 00 & 00 & 00 & 00 & 00 & 00 & 00 \\
\hline \multirow[t]{2}{*}{ Total } & 256 & 114 & 52 & 36 & 80 & 35 & 64 & 33 & 452 & 218 \\
\hline & \multicolumn{10}{|c|}{ H. impetiginosus } \\
\hline 1 & 46 & 46 & 00 & 00 & 15 & 15 & 17 & 17 & 78 & 78 \\
\hline 5 & 21 & 21 & 00 & 00 & 02 & 02 & 04 & 03 & 27 & 26 \\
\hline 10 & 01 & 01 & 00 & 00 & 00 & 00 & 00 & 00 & 01 & 01 \\
\hline 20 & 00 & 00 & 00 & 00 & 00 & 00 & 00 & 00 & 00 & 00 \\
\hline 30 & 00 & 00 & 00 & 00 & 00 & 00 & 00 & 00 & 00 & 00 \\
\hline \multirow[t]{2}{*}{ Total } & 68 & 68 & 00 & 00 & 17 & 17 & 21 & 20 & 106 & 105 \\
\hline & \multicolumn{10}{|c|}{ A. cearensis } \\
\hline 1 & 09 & 08 & 07 & 05 & 10 & 07 & 10 & 06 & 36 & 26 \\
\hline 5 & 08 & 08 & 00 & 00 & 00 & 00 & 09 & 08 & 17 & 16 \\
\hline 10 & 02 & 01 & 00 & 00 & 00 & 00 & 00 & 00 & 02 & 01 \\
\hline 20 & 00 & 00 & 00 & 00 & 00 & 00 & 00 & 00 & 00 & 00 \\
\hline 30 & 00 & 00 & 00 & 00 & 00 & 00 & 00 & 00 & 00 & 00 \\
\hline Total & 19 & 17 & 07 & 05 & 10 & 07 & 19 & 14 & 55 & 43 \\
\hline
\end{tabular}

More seedlings emerged in the nursery (Table 1) than in the field (Table 2), especially seedlings of $M$. urundeuva (1884 vs. 452) and A. cearensis (97 vs. 55); this difference was less pronounced (141 vs. 106) for H. impetiginosus. These data show that the conditions for seedling emergence were more favorable in the nursery than in the field, and that seed predation presumably decreases the seedling emergence for $M$. urundeuva (76\% predation, considering no predation under greenhouse conditions, and the 1,884 seedlings emerged under greenhouse compared to the 452 seedlings emerged under field conditions), $A$. cearensis (43\%, considering 97 and 55 emerged seedlings, respectively), and $H$. impetiginosa $(25 \%$, considering 141 and 106, respectively). However, the high levels of seed predation of the first species may be compensated by the survival rates of seedlings emerged in the field. This matter will be further considered in this paper. 
Further studies should evaluate why seedling emergence was observed only up to $10 \mathrm{~m}$ from the tree in the field (Table 2), considering that $M$. urundeuva and $A$. cearensis had potential to disperse a few seeds further beyond this range (Table 1). This is probably due to the predation of all the few $M$. urundeuva and A. ceaensis seeds or the absence of dispersed seeds beyond $10 \mathrm{~m}$ from the tree in four (H. impetiginosus) or three (A. cearensis) of the considered transects, as suggested by the nursery data.

According to Brito and Araújo (2009), high levels of predation of seeds are commonly observed under field conditions, especially in arid and semiarid environments; however, the reasons for $100 \%$ failure in seedling establishment beyond $10 \mathrm{~m}$ from the tree are not clear. According to Wang et al (2019), referring to the Janzen-Connell hypothesis, an increase in seed dispersal distance is expected to favor the survival of seedlings, because their natural enemies are more numerous close to the tree and do not need to compete directly with the adult plant that produced the seeds. However, this may be partially true if seedling survival is optimized at a certain distance from the tree. This optimal distance will be discussed later in this paper, but the maximum distance in the field $(10 \mathrm{~m})$ with surviving seedlings seems to contradict the Janzen-Connell hypothesis.

This pattern of seedling establishment indicates that $20 \mathrm{~m}$ is the approximate maximum distance between adult trees of these species to assure the establishment of their seedlings in the Caatinga environment, much less than the maximum distance of seed dispersal evidenced by the seedlings emerged from the floor material collected up to $30 \mathrm{~m}$ from the $M$. urundeuva trees and evaluated under nursery conditions.

At the end of the first rainy season after seed dispersal, the height of the 218 (M. urundeuva), 105 (H. impetiginosus), and 43 (A. cearensis) surviving seedlings that emerged in the field plots averaged (mean \pm standard error) 7.6 $\pm 0.4,5.6 \pm 0.6$, and $15.5 \pm 0.6 \mathrm{~cm}$, respectively; and their diameter averaged $0.95 \pm 0.01,1.34 \pm 0.02$, and $2.77 \pm 0.06 \mathrm{~mm}$, respectively. Seed characteristics probably affect the height and diameter of surviving seedlings. The average height and diameter of surviving $M$. urundeuva seedlings, which originated from light seeds, tended to be lower than the respective values for surviving $H$. impetiginosus and $A$. cearensis seedlings, which originated from heavy seeds.

The total rainfall depths in 2008 and 2009 totaled 1,119.4 and 1,594.4 mm, respectively; the monthly rainfall depth (PARAIIBA, 2010) (Figure 1A) probably affected the number of seedlings found in the field. The number of $M$. urundeuva seedlings peaked in mid-March, 2008 (Figure 1B), when rainfalls were abundant; the emergence:survival balance decreased markedly afterwards, meaning that emerged seedlings were outnumbered by seedlings that perished. The number of remaining seedlings of the other species (Figures $1 \mathrm{C}$ and 1D) increased during a longer period, up to the beginning of May, showing a stable or less pronounced decrease afterwards compared to those of $M$. urundeuva.
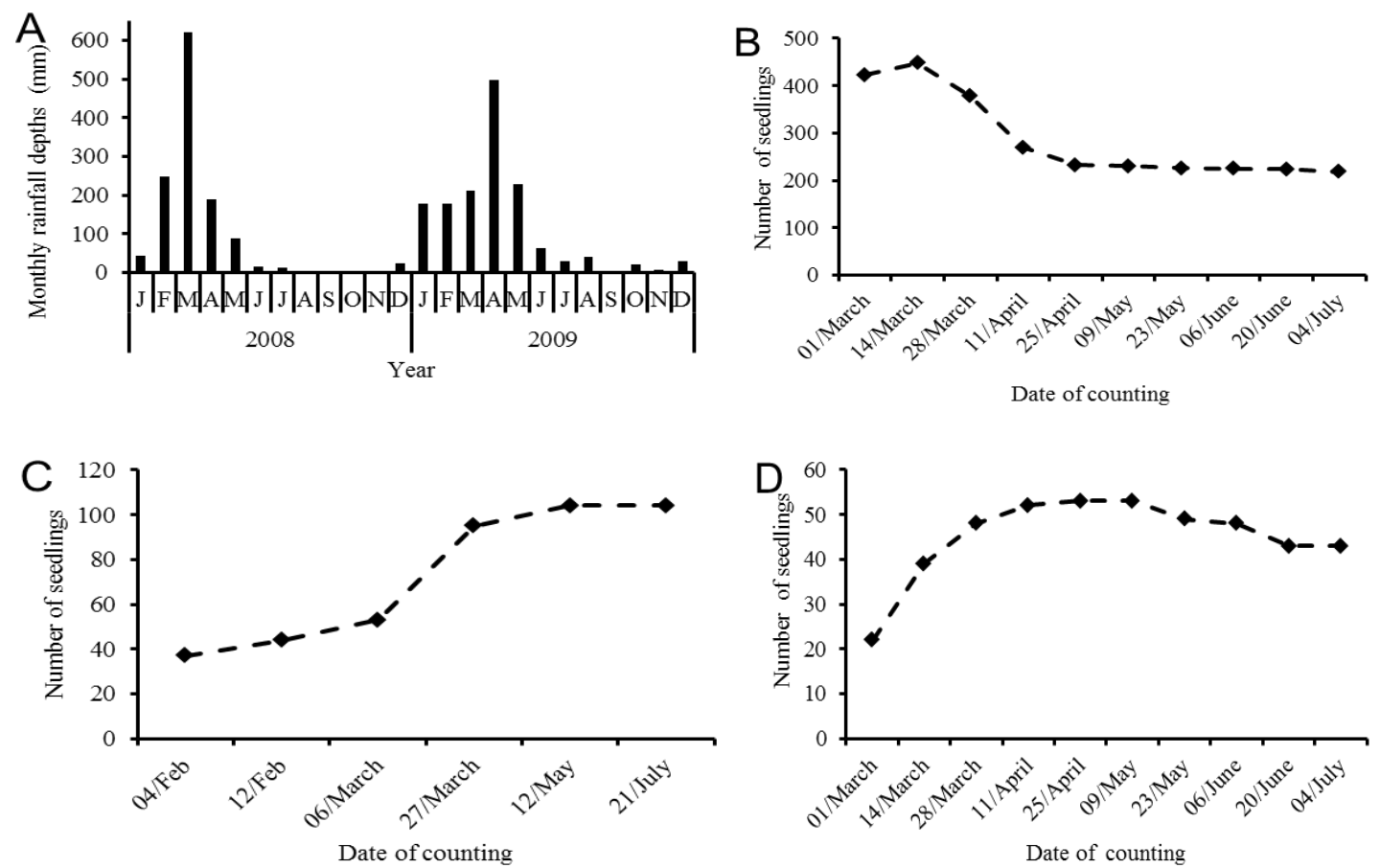

Figure 1. Monthly rainfall depths in 2008 and 2009, in Santa Terezinha, Paraíba, Brazil (PARAÍBA, 2010) (A), and number of seedlings of M. urundeuva (B), H. impetiginosus (C) and A. cearensis (D) in the field from the beginning to the end of the first rainy season after seed dispersal. 
The combined nursery and field data (Table 3 ) shows the number and percentage of viable seeds that lost viability due to factors impacting seeds in the field, since both data sets showing the quantity of seedlings emerged from the forest floor material with the same number of plots (and area) presented similarity around the trees. The comparison between the 1,884 and $452 M$. urundeuva seedlings that emerged under nursery and field conditions, respectively, showed an estimate of $24 \%$ $(452 * 100 / 1884=24)$ viable dispersed seeds able to successfully emerge in the field, i.e., $76 \%$ of them may have been predated or lost viability, as they could not be found as emerged seedlings in the field.

Table 3. Distance from the tree, number of potentially dispersed viable seeds (a) (see Table 1), number of emerged seedlings in the field during the first growing season (b) (See Table 2), estimated seed predation or loss of viability [(1-b/a) *100], number of surviving seedlings in the field at the end of the first growing season (c) (see Table 2), and estimated seed predation or loss of viability or seedling death at the end of the first growing season ([(1-c/a)*100] for Myracrodruon urundeuva, Handroanthus impetiginosus, and Amburana cearensis seeds.

\begin{tabular}{|c|c|c|c|c|c|}
\hline $\begin{array}{l}\text { Distance } \\
\text { from the tree } \\
\text { (m) }\end{array}$ & $\begin{array}{l}\text { Number of } \\
\text { potentially } \\
\text { dispersed } \\
\text { viable seeds } \\
\text { (a) }\end{array}$ & $\begin{array}{l}\text { Number of } \\
\text { emerged } \\
\text { seedlings } \\
\text { (b) }\end{array}$ & $\begin{array}{l}\text { Estimated seed } \\
\text { predation or loss } \\
\text { of viability } \\
(\%)\end{array}$ & $\begin{array}{l}\text { Number of } \\
\text { surviving } \\
\text { seedlings } \\
\text { (c) }\end{array}$ & $\begin{array}{l}\text { Estimated seed } \\
\text { predation or loss } \\
\text { of viability or } \\
\text { seedling death } \\
(\%)\end{array}$ \\
\hline & \multicolumn{5}{|c|}{ Myracrodruon urundeuva } \\
\hline 1 & 1156 & 281 & 75.69 & 100 & 91.35 \\
\hline 5 & 650 & 167 & 74.31 & 114 & 82.46 \\
\hline 10 & 68 & 4 & 94.12 & 4 & 94.12 \\
\hline 20 & 7 & 0 & 100.00 & 0 & 100.00 \\
\hline 30 & 3 & 0 & 100.00 & 0 & 100.00 \\
\hline \multirow[t]{2}{*}{ Total } & 1884 & 452 & 76.01 & 218 & 88.43 \\
\hline & \multicolumn{5}{|c|}{ Handroanthus impetiginosus } \\
\hline 1 & 108 & 78 & 27.78 & 78 & 27.78 \\
\hline 5 & 30 & 27 & 10.00 & 26 & 13.33 \\
\hline 10 & 3 & 1 & 66.67 & 1 & 66.67 \\
\hline 20 & 0 & 0 & - & - & - \\
\hline 30 & 0 & 0 & - & - & - \\
\hline \multirow[t]{2}{*}{ Total } & 141 & 106 & 24.82 & 105 & 25.33 \\
\hline & \multicolumn{5}{|c|}{ Amburana cearensis } \\
\hline 1 & 64 & 36 & 43.75 & 26 & 59.38 \\
\hline 5 & 26 & 17 & 34.62 & 16 & 38.46 \\
\hline 10 & 4 & 2 & 50.00 & 1 & 75.00 \\
\hline 20 & 3 & 2 & 33.33 & 0 & 100,00 \\
\hline 30 & 0 & 0 & 0 & - & - \\
\hline Total & 97 & 55 & 43.30 & 43 & 55.67 \\
\hline
\end{tabular}

The number of surviving seedlings at the end of the first rainy season after seed dispersal was equivalent to approximately $12 \%(218 * 100 / 1884)$ of the estimated viable dispersed $M$. urundeuva seeds, i.e., the dispersed seed decreased from 1,884 to 452 emerged seedlings and to 218 surviving seedlings in the field, equivalent to a reduction from $100 \%$ to $24 \%$ and $12 \%$, respectively. The quantities and percentages were, respectively, 141 to 106 and 105 for $H$. impetiginosus, corresponding to decreases from $100 \%$ to $75 \%$ and $74 \%$; and 97 to 55 and 43 for A. cearensis, corresponding to decreases from $100 \%$ to $57 \%$ and $44 \%$.

These data show a probable positive relation between number of produced seeds and percentages of seed viability loss and seedling mortality; trees that produce large amount of seeds (and light seeds), such $M$. urundeuva, have higher level of seed viability loss and seedling mortality than those that produce few (and heavy) seeds (A. cearensis). However, factors other than weight and number of produced seeds should affect the percentage of viability loss, since $H$. impetiginosus seeds occupy an intermediate position regarding these factors, but they presented the highest viability among the three tree species.

Although showing high percentage of seed viability loss and seedling mortality, $218 \mathrm{M}$. urundeuva seedlings endured to the end of the first rainy season after seed dispersal, contrasting with the $105 \mathrm{H}$. impetiginosus surviving seedlings and $43 \mathrm{~A}$. cearensis surviving seedlings. This corresponds to an approximate ratio of $24: 11: 5$ between the respective numbers of surviving seedlings. This means that the large number of produced seeds and emerged seedlings from $M$. urundeuva more than compensate for the high levels of seed viability loss and seedling mortality in early stages of seedling 
establishment when compared to what happened to $H$. impetiginosus and $A$. cearensis.

The estimated percentage of seed predation or loss of viability or seedling death was minimal around $5 \mathrm{~m}$ from the trees (Table 3 ). Considering the average values of crown diameter $(7.2 \leq$ crown diameter $\leq 11.0 \mathrm{~m}$ ), this optimal distance is found just at or a little further from the direct influence of the canopy of the tree that produced the seeds, indicating more favorable environmental conditions for seedling establishment close to the periphery of the tree canopy. Further studies are necessary to establish these environmental conditions.

These high failure values show the reproductive efforts (flowers, fruits, and seeds) of these species, and certainly of other Caatinga trees, for seedling recruitment. Monitoring these recruited seedlings in the following years certainly will show the death of more seedlings and the remarkable efforts of these trees to generate fully established adult plants.

Soil moisture probably was not a limiting factor for emergence and survival of seedlings from these native species during the study period, because they are adapted to the average annual rainfall depth of the region (around $700 \mathrm{~mm}$ ), which is lower than the 1,119.4 and 1,594.4 $\mathrm{mm}$ observed during 2008 and 2009, respectively (Figure 1A).

In the field, most of the seedlings emerged up to the end of March. The period for emergence of $M$. urundeuva seedlings was longer in nursery than in field conditions ( 6 vs. 4 weeks). Contrastingly, the emergence of $H$. impetiginosus and $A$. cearensis seedlings occurred during 6 weeks in the nursery and within a 9-week period in the field.

The meticulous data collection under nursery conditions contrasting with the penumbra on the forest environment, and a small seedling size may explain why $M$. urundeuva seedlings were supposed to emerge for longer and shorter periods of time, respectively. The other two species had a longer seedling emergence period under field than under nursery conditions, probably due to the sub-optimal light and substrate moisture conditions in the field. However, considering that M. urundeuva seedlings emerge faster than $H$. impetiginosus and $A$. cearensis ones (4 vs. 9 weeks), M. urundeuva presents a 5week longer period for the establishment of seedlings than the other two species, in which they can develop and get stronger before the onset of the dry season, increasing the probability of survival until the following rainy season.

The production of heavy seeds allows the development of more robust seedlings, as reported by Pagliarini et al. (2014) for Hymeneae courbaril L. var. Stilbocarpa. Thus, the strategy of fast emergence of seedlings may be more ecologically important for the establishment of $M$. urundeuva seedlings than $H$. impetiginosus and $A$. cearensis seedlings, because the last two species produce seeds 10- to 50-fold heavier than M. urundeuva seeds.

The mortality of seedlings that emerged in the filed differed between the tree species evaluated. The number of emerged $M$. urundeuva seedlings were 452 , of which 218 survived to the end of the first rainy season (Table 3 ). This means that 234 plants died (220 from March to April, and 14 died from May to July), even with low rainfall depths. The mortality of emerged $H$. impetiginosus seedlings was minimal; one of the 106 seedlings died in the beginning of May, showing that these seedlings resisted to biotic and abiotic factors in the field during the first months. Twelve out of the 55 emerged $A$. cearensis seedlings died in the field (one in March, one in April, and 10 in June-July), when rainfalls decreased, although other factors contributed to the increase of seedling mortality.

The numbers of emerged and surviving seedlings in the sampled plots decreased as the distance from the tree increased (Table 3). However, this does not necessarily mean that the absolute numbers of emerged and surviving seedlings decreased as the distance from the tree increased. The estimated rate of seed predation or viability loss or seedling death showed a minimal value around 5 $\mathrm{m}$ from the trees, and 12 plots sampled at each distance represent the crescent area within the belt centered at 1, 5, 10, 20, and $30 \mathrm{~m}$ from the trees.

The areas of the three $0.8-\mathrm{m}$ wide belts centered at $1,5,10,20$, and $30 \mathrm{~m}$ from the $M$. urundeuva trees resulted in 15.08, 75.40, 150.80, 301.59 , and $452.39 \mathrm{~m}^{2}$, respectively; and the areas of the three 1.24-m wide belts centered at 1, 5, 10, 20, and $30 \mathrm{~m}$ from the $H$. impetiginosus and $A$. cearensis trees resulted in $23.37,116.87,233.74,467.47$, and $701.21 \mathrm{~m}^{2}$, respectively. The estimated number of emerged seedlings ( $E$ value in Table 4$)$ and surviving seedlings ( $F$ value in Table 4$)$ in the three field belts, considering the respective distance and belt area, peaked at around $5 \mathrm{~m}$ from the tree. Further data manipulation shows that the $F: E$ ratio tended to a maximum at approximately $5 \mathrm{~m}$ from the three species, especially for $M$. urundeuva. The ratio found for this species $(* 100)$ increased from 8.7 to 17.5 and, then, decreased to 5.9 , respectively at 1,5 , and $10 \mathrm{~m}$ from the tree. These values refer to survival rates of emerged seedlings; at $1 \mathrm{~m}$ from $M$. urundeuva trees, $8.7 \%$ of the emerged seedlings survived to the end of the first rainy season after seed dispersal, $17.5 \%$ survived at $5 \mathrm{~m}$, and $5.9 \%$ survived at $10 \mathrm{~m}$. 
Table 4. Distances from tree and respective areas of 12 circular plots* (A) and 3 belts** (B) centered at each distance, number of emerged seedlings in the material collected from 12 plots under greenhouse conditions (C) (see Table 1), number of surviving seedlings in 12 field plots (D) (see Table 2), estimated number*** of emerged seedlings in 3 belts (E), estimated number**** of surviving seedlings in 3 belts $(\mathrm{F})$, and $\mathrm{E}$ : $\mathrm{F}$ ratio for three tree species.

\begin{tabular}{|c|c|c|c|c|c|c|c|}
\hline $\begin{array}{l}\text { Distance } \\
\text { from the } \\
\text { tree } \\
(\mathrm{m})\end{array}$ & $\begin{array}{c}\text { Area of } 12 \\
\text { circular } \\
\text { plots }(\mathrm{A}) \\
\left(\mathrm{m}^{2}\right)\end{array}$ & $\begin{array}{c}\text { Area of } 3 \\
\text { belts } \\
\text { centered } \\
\text { at each } \\
\text { distance }(\mathrm{B}) \\
\left(\mathrm{m}^{2}\right)\end{array}$ & $\begin{array}{l}\text { Number of } \\
\text { emerged } \\
\text { seedlings } \\
\text { in } 12 \\
\text { nursery } \\
\text { plots (C) }\end{array}$ & $\begin{array}{l}\text { Number of } \\
\text { surviving } \\
\text { seedlings } \\
\text { in } 12 \\
\text { field plots } \\
\text { (D) }\end{array}$ & $\begin{array}{l}\text { Estimated } \\
\text { number of } \\
\text { emerged } \\
\text { seedlings } \\
\text { in } 3 \text { belts } \\
\left(\mathrm{E}=\mathrm{B}^{*} \mathrm{C} / \mathrm{A}\right)\end{array}$ & $\begin{array}{c}\text { Estimated } \\
\text { number of } \\
\text { surviving } \\
\text { seedlings } \\
\text { in } 3 \text { belts } \\
\left(\mathrm{F}=\mathrm{E}^{*} \mathrm{D} / \mathrm{C}\right. \\
\text { or } \mathrm{F}=\mathrm{B} * \mathrm{D} / \mathrm{A})\end{array}$ & $\begin{array}{c}\mathrm{F}: \mathrm{E} \\
\text { Ratio } \\
(100 * \mathrm{~F} / \mathrm{E})\end{array}$ \\
\hline & \multicolumn{7}{|c|}{ Myracrodruon urundeuva } \\
\hline 1 & 6.0 & 15.08 & 1156 & 100 & 2905 & 251 & 8.7 \\
\hline 5 & 6.0 & 75.40 & 650 & 114 & 8168 & 1433 & 17.5 \\
\hline 10 & 6.0 & 150.80 & 68 & 4 & 1709 & 101 & 5.9 \\
\hline 20 & 6.0 & 301.59 & 7 & 0 & 352 & 0 & 0 \\
\hline \multirow[t]{3}{*}{30} & 6.0 & 452.39 & 3 & 0 & 226 & 0 & 0 \\
\hline & & & 1884 & 218 & & & \\
\hline & \multicolumn{7}{|c|}{ Handroanthus impetiginosus } \\
\hline 1 & 14.4 & 23.37 & 108 & 78 & 175 & 127 & 72.2 \\
\hline 5 & 14.4 & 116.87 & 30 & 26 & 243 & 211 & 86.7 \\
\hline 10 & 14.4 & 233.74 & 3 & 1 & 49 & 16 & 33.3 \\
\hline 20 & 14.4 & 467.47 & 0 & 0 & 0 & 0 & - \\
\hline \multirow[t]{3}{*}{30} & 14.4 & 701.21 & 0 & 0 & 0 & 0 & - \\
\hline & & & 141 & 105 & & & \\
\hline & \multicolumn{7}{|c|}{ Amburana cearensis } \\
\hline 1 & 14.4 & 23.37 & 64 & 26 & 104 & 42 & 40.6 \\
\hline 5 & 14.4 & 116.87 & 26 & 16 & 211 & 130 & 61.5 \\
\hline 10 & 14.4 & 233.74 & 4 & 1 & 65 & 16 & 25.0 \\
\hline 20 & 14.4 & 467.47 & 3 & 0 & 97 & 0 & 0 \\
\hline \multirow[t]{2}{*}{30} & 14.4 & 701.21 & 0 & 0 & 0 & 0 & - \\
\hline & & & 97 & 43 & & & \\
\hline
\end{tabular}

* = diameter of circular plots: $0.80 \mathrm{~m}$ for M. urundeuva, and $1.24 \mathrm{~m}$ for H. impetiginosus and A. cearensis; ** $=$ width of belts centered at each distance from the trees: $0.80 \mathrm{~m}$ for $M$. urundeuva, and $1.24 \mathrm{~m}$ for $H$. impetiginosus and A. cearensis; the area of the belts was calculated by the difference between the areas of two circles; $* * *=$ considering the same seedling emergence rate observed in greenhouse at the same distance from the tree; $* * * *=$ considering the same estimated survival rate observed in the field plots at the same distance.

The F:E found for H. impetiginososus increased from 72.2 to 86.7 and, then, decreased to 33.3 at 1,5 , and $10 \mathrm{~m}$ from the tree, respectively; and the F:E found for A. cearensis were 40.6, 61.5, and 25.0, respectively. These data confirm those in Table 3 (a minimum of seed predation or loss of viability or seedling death around $5 \mathrm{~m}$ from the tree). Certainly, further studies are needed to establish which conditions present at around $5 \mathrm{~m}$ from the trees affect positively the initial establishment of seedlings of such trees.

\section{CONCLUSIONS}

There are no viable seeds of Myracrodruon urundeuva, Handroanthus impetiginosus, and Amburana cearensis on the forest floor just before seed dispersal.

Seed dispersal of these tree species occurs predominantly towards the North and West from the parent trees;
There are viable seeds of these species in the seedbank just after seed dispersal, reaching 30, 10, and $20 \mathrm{~m}$ from adult Myracrodruon urundeuva, Handroanthus impetiginosus, and Amburana cearensis trees, respectively;

Most dispersed seeds remain viable until the beginning of the following rainy season, and the seedling emergence in the field is fast (4 to 9 weeks), especially for Myracrodruon urundeuva;

Seedling emergence was observed mainly until March; it subsequently ceased for Myracrodruon urundeuva and sharply decreased for Handroanthus impetiginosus and Amburana cearensis;

No emerged seedlings survived in the field, beyond $10 \mathrm{~m}$ from the parent tree, to the end of the first rainy season after seed dispersal, and these surviving seedlings represented, respectively, $12 \%$, $74 \%$, and $44 \%$ of the estimated total number of dispersed viable seeds from Myracrodruon urundeuva, Handroanthus impetiginosus, and Amburana cearensis;

There are more surviving seedlings of 
Myracrodruon urundeuva than those of Handroanthus impetiginosus and Amburana cearensis at the end of the first rainy season after seed dispersal, presenting a ratio of approximately 24:11:5;

An approximate distance of $5 \mathrm{~m}$ from the tree favors seed viability and seedling survival, allowing a higher number of seedlings to emerge and a higher percentage of seedlings to survive than shorter or longer distances from the parent trees;

Height and diameter of the surviving seedlings at the end of the first rainy season after seed dispersal are, respectively (mean \pm standard error): $7.6 \pm 0.4 \mathrm{~cm}$ and $0.95 \pm 0.04 \mathrm{~mm}$ for Myracrodruon urundeuva, $5.6 \pm 0.1 \mathrm{~cm}$ and $1.35 \pm 0.03 \mathrm{~mm}$ for Handroanthus impetiginosus, and $15.5 \pm 0.6 \mathrm{~cm}$ and $2.77 \pm 0.06 \mathrm{~mm}$ for Amburana cearensis.

\section{REFERENCES}

BASKIN, C. C.; BASKIN, J. M. Seeds: ecology, biogeography, and evolution of dormancy and germination. 1. ed. New York, NY: Academic Press, 1998. 666 p.

BRASIL. Ministério do Meio Ambiente. IBAMA Reconhece a Reserva Particular do Patrimônio Natural da Fazenda Tamanduá, em Santa Terezinha - PB, [1998]. Disponível em: <https:// pesquisa.in.gov.br/imprensa/jsp/visualiza/index.jsp? data $=31 / 07 / 1998 \&$ jornal $=1 \&$ pagina $=139 \&$ totalArqui vos $=152>$. Acesso em: 20 ago. 2020 .

BRITO, L. B. M.; ARAÚJO, F. S. Banco de sementes de Cordia oncocalyx Allemão em uma área de Caatinga sobre planossolo. Revista Caatinga, 22: 206-212, 2009.

COSTA, R. C.; ARAÚJO, F. S. Densidade, germinação e flora do banco de sementes do solo no final da estação seca em uma área de Caatinga, Quixadá, CE. Acta Botânica Brasílica, 17: 259-264, 2003.

FERNANDES, M. F.; QUEIROZ, L. P. Vegetação e flora da Caatinga, Ciência e Cultura, 70: 51-56, 2018.

GOMES, V. G. N.; QUIRINO, Z. G. M. Síndromes de dispersão de espécies vegetais no Cariri Paraibano. Revista Brasileira de Geografia Física, 9: 1157-1167, 2016.

LIMA, V. V. F. et al. Germinação de espécies arbóreas de floresta estacional decidual do vale do rio Paranã em Goiás após três tipos de armazenamento por até 15 meses. Biota Neotropica, 8: 89-97, 2008.

LÚCIO, A. M. F. N.; SILVA, G. H.; LOPES, I. S. Influência da época de coleta e armazenamento na qualidade fisiológica da semente de cumarú. Engenharia Ambiental, 7: 48-56, 2010.

MARTINELLI, G.; MORAES, M. A. (Orgs.) Livro vermelho da flora do Brasil. 1. ed. Rio de Janeiro, RJ: Andrea Jakobson: Instituto de Pesquisas Jardim Botânico do Rio de Janeiro, 2013. 1100 p.

MEIADO, M. V. Banco de sementes no solo da Caatinga, uma Floresta Tropical Seca no Nordeste do Brasil. Informativo ABRATES, 24: 39-43, 2014.

PAGLIARINI, M. K. et al. Influência do tamanho de sementes e substratos na germinação e biometria de plântulas de jatobá. Tecnologia \& Ciência Agropecuária, 8: 33-38, 2014.

PARAÍBA. Agência Executiva de Gestão das Águas do Estado da Paraíba. Meteorologia: monitoramento mensal das chuvas por município. Disponível em: http://www.aesa.pb.gov.br/aesa-website/. Acesso em: 25 fev. 2010.

SANTOS, C. A. et al. Germinação de sementes de duas espécies da caatinga sob déficit hídrico e salinidade. Pesquisa Florestal Brasileira, 36: 219224, 2016

SILVA, M. C. N. A.; RODAL, M. J. N. Padrões das síndromes de dispersão de plantas em áreas com diferentes graus de pluviosidade, PE, Brasil. Acta Botânica Brasílica, 23: 1040-1047, 2009.

SIQUEIRA FILHO, J. A. et al. Guia de campo de árvores da Caatinga. 1. ed. Petrolina, PE: Editora e Gráfica Franciscana Ltda, 2009. 64 p.

WANG, R. et al. Distance-dependent seed-seedling transition in the tree Castanopsis sclerophylla is altered by fragment size. Communications Biology: 2: 277-287, 2019. 